${ }^{\circ}$ Entomologica Fennica. 20 September 1996

\title{
On the identity of Bledius fontinalis (Coleoptera Staphylinidae) and its distribution in Finland
}

\author{
Tom Clayhills
}

\begin{abstract}
Clayhills, T. 1996: On the identity of Bledius fontinalis (Coleoptera, Staphylinidae) and its distribution in Finland. - Entomol. Fennica 7:67-68.

The status of Bledius fontinalis Bernhauer is discussed and its distribution in Finland is revised. The nomenclatural confusion is straightened out. The male genitalia of $B$. erraticus Erichson are illustrated. According to these the only species of the "erraticus"-group occurring in the northern countries is $B$. erraticus.
\end{abstract}

Tom Clayhills, Tennbyntie 33-35 B 4, SF-21600 Parainen, Finland

Received 1 November 1994, accepted 21 June 1995

In the northern countries, Bledius erraticus Erichson, 1839 was earlier separated into two subspecies, of which the nominate ssp. was found only from southern Sweden ( $S k$ ), and B. erraticus bosnicus Bernhauer, 1902 in Norway, northern Sweden and NW Russia (Lindroth 1960). Strand (1946) considered B. bosnicus Bernhauer, 1902 as a valid species (with B. fontinalis Bernhauer, 1929 as a synonym), but he, as well as Jansson \& Palm (1936) suspected that the actual name should be $B$. erraticus. Later the name $B$. fontinalis was used by Silfverberg (1979) and Herman (1986) for B. bosnicus.

In his revision of Bledius, Herman (1986) mentions all three species and announced $B$. fontinalis from Finland, Kuusamo (although probably taken from the Russian side of the border). In 1987 the species was found in $L i$ : Utsjoki, Nuorgam (Clayhills 1988 , as $B$. fontinalis). Herman also mentioned $B$. erraticus from Finland, Paanajärvi (the locality is actually on the Russian side of the current border). According to him B. bosnicus is found in the Alps of the former Yugoslavia and Austria. Lohse and Lucht (1989) mentioned it also from Germany.

Lohse and Lucht (1989) pointed out the differences between these three species and added drawings of their male genitalia (Fig. 1). According to their descriptions all Finnish, Swedish and Nor- wegian, as well as the Russian specimens from the Kola Peninsula and Paanajärvi regions must be considered to belong to the real B. erraticus on the basis of different morphological characters. The real B. fontinalis is found in Germany, Austria and Switzerland mostly at altitudes of $1600 \mathrm{~m}$ and higher (Lucht 1987, Lohse \& Lucht 1989).

The elytra of B. erraticus are usually as long as or clearly shorter than the width of both elytra together. There is, however a clear difference in the southern population ( $S k$ ) compared to the northern ones ( $L i, L p s, K s$ and TRi) in this respect. The southem population has constantly very short elytra, clearly shorter than their width together, while the length of the elytra in the northern populations seems to vary from almost as short as in the southern population to as long as, sometimes even a little longer than their width together. The other species should have clearly longer elytra. The ratio lengthwidth of the pronotum seems to vary in both the northern and southern populations. The northern specimens seem to have somewhat more sinuated hind corners of the pronotum. Furthermore, the southern specimens differ from the northern by a clearly lighter reddish colour of the elytra though they are sometimes darker around the scutellum and the suture. 


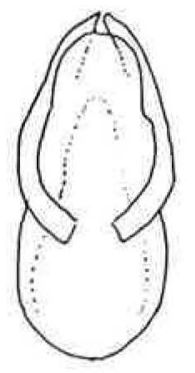

38

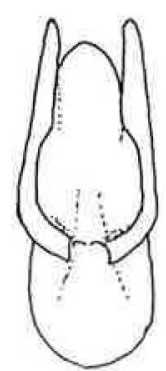

37

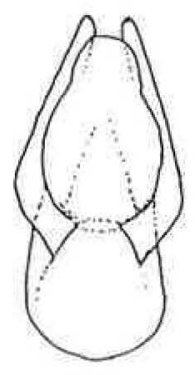

$37 a$
Fig. 1. The male genitalia of 38 B.fontinalis Bernhauer, 37 B.erraticus Erichson, and 37 a B.bosnicus Bernhauer, (from Lohse \& Lucht 1989, with original numbers).

The most typical difference is the structure of the male genitalia. The illustrations in Lohse \& Lucht (1989) clearly show the narrowness of the penis and the long and almost straight parameres of B.erraticus compared to the other two species (Fig. 1). The pictures are schematically drawn and seem to lack the thin membranous outer part of the penis near the apex. In the genitalia of the southern population from $S k$ and a northem population from $L i$ there are no clear differences to be seen either in the outer form or inner structures (Fig. 2). Thus the view already adopted by Jansson and Palm (1936) that the southern and northern populations in Fennoscandian countries are only variations of B.erraticus is correct.

So far the species has been found in Finland from two sites. The first is $L i$ : Utsjoki, Nuorgam, on the sandy shoreline of the Ylä-Pulmanki River which has sparse stands of grasses. The other site is $K s$ : Kuusamo, Jäkälämutka on the sandy shoreline of the river Oulankajoki quite close to the Russian border, on similar habitats as in the former place (Jyrki Muona pers. comm.).
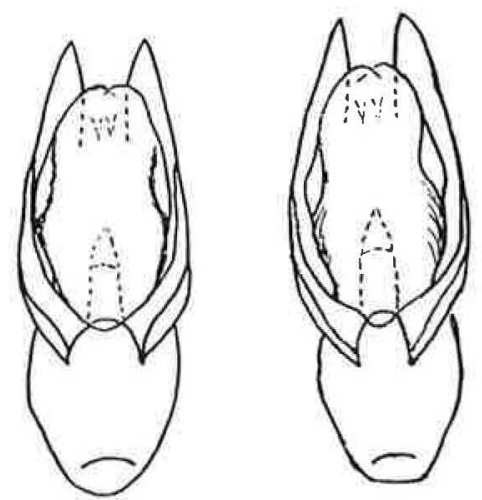

Fig. 2. The male genitalia of B.erraticus Erichson, on the left a southern specimen from Sweden, Skåne and right a northern specimen from Finland, Utsjoki Original.

Acknowledgements. I wish to thank Bengt Ehnström and Jyrki Muona for loan of Bledius erraticus specimens.

\section{References}

Clayhills, T. 1988: Lyhytsiipishavaintoja Inarin Lapista kesällä 1987. — Notulae Entomol. 68:150.

Herman, L. H. 1986: Revision of Bledius. Part IV. Classification of species groups, phylogeny, natural history, and catalogue (Coleoptera, Staphylinidae, Oxytelinae). Bull. Am. Mus. Nat. Hist. 184:1-367.

Jansson, A. \& Palm, T. 1936: Resultat av en coleopterologisk studieresa till nordvästra Jämtlands fjälltrakter. Entomol. Tidskr. 57:180-226.

Lindroth, C. H. (ed.) 1960: Catalogus Coleopterorum Fennoscandiae et Daniae. - Lund, 467 pp.

Lohse, G. A. \& Lucht, W. H. 1989: Die Käfer Mitteleuropas 12. 1 Suplementband mit Katalog. - Krefeld. 345 pp.

Lucht, W. H. 1987: Die Käfer Mitteleuropas. Katalog. Krefeld, 342 pp.

Silfverberg, H. 1979: Enumeratio Coleopterorum Fennoscandiae et Daniae. - Helsingfors, $79 \mathrm{pp}$.

Strand, A. 1946: Nord-Norges Coleoptera. Tromsö Mus. Årsheft. 67:1-629. 